\title{
The natural history of pregnancy-related enhanced myometrial vascularity
}

\section{following miscarriage}

\author{
Karen Grewal MRCOG ${ }^{1}$ Maya Al-Memar MRCOG ${ }^{1}$, Hanine Fourie MBBS BSc ${ }^{1}$, Catriona \\ Stalder MRCOG ${ }^{2}$, Dirk Timmerman Ph.D ${ }^{3}$., Tom Bourne Ph.D. FRCOG ${ }^{1,2 \& 3}$
}

1. Tommy's National Centre for Miscarriage Research. Institute of Reproductive \& Developmental Biology, Imperial College London, Hammersmith Hospital Campus, Du Cane Road, London, UK

2. Queen Charlotte's Hospital, Hammersmith Hospital Campus, Imperial College London, Du Cane Road, London, UK

3. Department of Obstetrics and Gynecology, University Hospitals KU Leuven, Leuven, Belgium

Corresponding author:

Karen Grewal MBBS BSc MRCOG

Clinical Research Fellow, Institute of Reproductive \& Developmental Biology

Imperial College London Hammersmith Hospital Campus

Du Cane Road, London, W12 0NN

karen.grewal04@imperial.ac.uk

KEYWORDS; Abortion, Spontaneous, Miscarriage, Ultrasonography, Doppler, Color, Enhanced

myometrial vascularity, Arteriovenous malformations

Short title: Enhanced Myometrial Vascularity

This article has been accepted for publication and undergone full peer review but has not been through the copyediting, typesetting, pagination and proofreading process which may lead to differences between this version and the Version of Record. Please cite this article as doi: $10.1002 /$ uog. 21872 


\section{Contribution}

\section{What are the novel findings of this work?}

The true incidence of EMV is unknown. Reports in the literature are often retrospective case series that focus on selected populations. We have shown the incidence of EMV following miscarriage is relatively low (1.52\%). Furthermore, our data show that both surgical or expectant management was safe in our cohort, with no cases of haemorrhage.

\section{What are the clinical implications of this work?}

Previously the term EMV was used interchangeably with acquired arteriovenous malformation and curettage was discouraged. This study demonstrates that expectant or surgical management is safe in cases of EMV in relation to miscarriage. This study will help guide management of EMV in relation to miscarriage. 


\begin{abstract}
Objectives

Our primary aim was to report the incidence of enhanced myometrial vascularity (EMV) in consecutive women following first trimester miscarriage who attended our early pregnancy assessment unit. We further aimed to evaluate the clinical presentation, and complications associated with the condition.
\end{abstract}

\title{
Methods
}

A prospective cohort study conducted in a London teaching hospital between June 2015 and June 2018. Consecutive patients with an observation of EMV by transvaginal ultrasonography (TVS) were included. The diagnosis was made following the subjective identification of EMV using color Doppler ultrasonography and a peak systolic velocity (PSV) $\geq 20 \mathrm{~cm} / \mathrm{sec}$ within the collection of vessels. Women were followed up with repeat scans every 14 days. Management was expectant unless intervention was indicated because of excessive or prolonged bleeding, the persistent presence of retained tissue in the endometrial cavity or patient choice. The final clinical outcome was recorded. Time to resolution was defined as the date of EMV detection until resolution was observed. The time to cessation of symptoms was also documented.

\section{Results}

Forty patients were diagnosed with EMV during the study period following miscarriage and included in the study. There were 2627 first trimester losses in the department during this study period, hence the incidence of EMV following miscarriage was $1.52 \%$. All cases were associated with ultrasound evidence of retained products of conception (RPOC) at presentation (mean dimensions 
$22 \times 20 \times 20 \mathrm{~mm})$. Thirty-one patients initially opted for expectant management, of which 18 were successful, five were lost to follow up and eight subsequently had surgical evacuation due to patient wishes. No expectantly managed case required emergency intervention. Nine patients chose surgical evacuation as primary treatment. No strong correlation was seen between PSV and blood loss at surgery (PSV range $20-148 \mathrm{~cm} / \mathrm{sec}$, median $47 \mathrm{~cm} / \mathrm{sec}$ ). The estimated blood loss in all surgically managed cases ranged from $20-300 \mathrm{~mL}$. Products of conception were confirmed in all cases sent for histological analysis. For cases successfully managed expectantly, the mean time to resolution was 49 days (range, 21-84). The cases initially surgically managed had a mean time to resolution of 10.6 days (range, 3-29).

\section{Conclusion}

Our study suggests EMV is an uncommon finding following miscarriage and associated with the presence of retained products of conception (confirmed histologically in all cases surgically managed). Expectant management is a safe option in our cohort, with minimal bleeding, although associated with protracted time to resolution. When patients opt for surgery the maximum blood loss was $300 \mathrm{mls}$, but no patient required a blood transfusion or embolization. 


\section{Introduction}

Enhanced myometrial vascularity (EMV) is a term used to describe a tortuous, rich vascular network within the myometrium, which may follow a recent intrauterine pregnancy. Blood flow within EMV's has been objectively reported to have a peak systolic velocity (PSV) of $\geq 20 \mathrm{~cm} / \mathrm{sec}^{1}$

The true incidence of EMV is unknown as cases in the literature are often reported interchangeably with arteriovenous malformation (AVM). The term AVM refers to a short circuit in the arterial and venous blood supply. ${ }^{1}$ Such malformations are rare and can be congenital or acquired. Acquired AVMs are associated with infection, curettage, therapeutic abortion, pelvic surgery, endometrial carcinoma and gestational trophoblastic disease. ${ }^{2}$ Mulliken et al described the histology of AVMs as errors of morphogenesis and hence unlikely to spontaneously regress. ${ }^{3}$ Reports in the literature which detail the resolution of acquired AVMs over time are unlikely to represent true AVMs and probably reflected the presence of EMV. ${ }^{4,5}$ This concept was described by Timmerman et al and the emerging belief is that EMV and AVM are separate entities. ${ }^{6,7}$

Angiography is the gold standard for the diagnosis of AVM. ${ }^{8}$ The increased use of color Doppler has led to increased reporting of apparent vascular malformations. However, not all correspond to angiography findings, which potentially demonstrates EMV rather than true AVM.

There remain uncertainties over the optimum management of EMV or how to distinguish them from true AVM. In cases of EMV, removal of retained products of conception (RPOC) or conservative management has been reported. Although minimal complications have been shown,

these studies are often small retrospective case series. ${ }^{6,7,12}$ We do not know the natural history of EMV if expectant management is followed and whether ultrasound features predict complications. 
The primary aim of this study was to evaluate the incidence of EMV in consecutive women attending an early pregnancy assessment unit with a miscarriage. The secondary aim was to report the complications in women with EMV who choose expectant or surgical management. 


\section{Methods}

We undertook a prospective audit at Imperial College Healthcare Trust (registration number GRM_013) between June 2015 and June 2018 of all consecutive patients diagnosed with enhanced myometrial vascularity. Given that the prevalence of EMV after miscarriage was not known prior to this study, it was not possible to have a precise estimate of study size prior to its start. By including data over a 3-year period with approaching 2000 miscarriages, we believed that the prevalence of EMV found in the study would be an accurate reflection. All first trimester losses were routinely scanned with TVS and color Doppler used to identify a region of enhanced vascularity. Enhanced myometrial vascularity was defined as a hypervascular area within the myometrium using transvaginal color Doppler ultrasonography with a PSV using pulsed Doppler of $\geq 20 \mathrm{~cm} / \mathrm{sec}$ within the collection of vessels. All patients identified as EMV after initial assessment were referred to the same clinicians (KG/TB) for confirmation and the highest measured PSV was documented using a standardized approach. Having identified the area of enhanced vascularity with color Doppler, the pulse repetition frequency (PRF) was increased until only the vessels with the highest velocity remained visible. ${ }^{13}$ A narrow sample volume of $(1 \mathrm{~mm})$ was then placed over the area of interest and the highest velocity flow was recorded. (Figure $1 \mathrm{~A}$ ) All patients were examined with either a Samsung WS80 or GE Voluson E10 ultrasound system with color Doppler imaging and vaginal probe frequencies of $4-7 \mathrm{MHz}$. The use of specific ultrasound systems and clinicians provided standardisation and contributed to efforts to minimise bias. Figure $1 \mathrm{~B}$ and $\mathrm{C}$ represents a $\mathrm{B}$ mode and corresponding color Doppler image of enhanced myometrial vascularity. The presence or absence of retained tissue was noted and the size measured in three orthogonal planes. The PSV was also recorded from the area of EMV. Clinical data including, patient age, ethnicity, reproductive 
status, surgical history, initial clinical presentation, bleeding score and management were recorded. The hCG was not measured as UK national guidance does not advocate the use of hCG to guide management of miscarriage. A modified pictorial blood assessment chart (PBAC) was used to assess bleeding scores at initial presentation. ${ }^{14}$ The time to resolution was defined as the date of EMV detection to intervention or when RPOC/EMV were no longer visible, in those cases managed expectantly. Surgical management in this study was defined as evacuation of the RPOC using dilation and suction aspiration +/- hysteroscopy under general anaesthesia. The estimated blood loss, need for blood transfusion and complication rate were documented. All tissue removed was sent for histological examination. Statistical analysis was performed using SPSS software package version 25 and a significance level of 0.05 was selected. 


\section{Results}

During the study period 2627 first trimester losses were recorded in the department. A total of 40 consecutive patients with EMV following miscarriage were included in the study, giving an incidence of $1.52 \%$. The mean age of the women was 34 (range, 22-44), the mean parity 1.3 (range, $0-7$ ) and the gestational age at presentation of EMV ranged from 6 to 12 weeks from the last menstrual period. Women presented after miscarriage with the following clinical scenarios: incomplete miscarriage $(n=23)$, failed medical management of miscarriage with RPOC $(n=8)$, and failed surgical management of miscarriage $(n=9)$, (Table 1B).

The average bleeding score at initial presentation was 2.7 (moderate blood loss), and there was no difference in bleeding between those that elected for initial expectant management or surgery. All cases were associated with RPOC, and the mean dimensions were $22 \times 20 \times 20 \mathrm{~mm}$ on the day of presentation, with the widest diameter $42 \mathrm{~mm}$. Products of conception were confirmed in all specimens that were sent for analysis following surgery ( $n=17 / 17)$.

Initial Expectant management

Of the women who initially chose expectant management $(n=26), 18$ resolved their miscarriage without intervention and eight cases opted for surgery due to patient choice to avoid the need for further follow up visits. All eight cases had surgical management with hysteroscopy as an adjunct to the evacuation procedure. There were no complications and the EBL ranged from $20-300 \mathrm{~mL}$. Five cases were lost to follow up. The time to resolution for those managed expectantly from the outset 
was 48 days. During this follow up, bleeding was reported as intermittent. No patient required emergency intervention be it surgery, blood transfusion or embolization (Table 2).

Initial surgical management

Nine women opted for surgery in the first instance of which seven were performed without complications. However, two cases had persistent RPOC and required a repeat procedure under hysteroscopic guidance to ensure resolution. The EBL range at surgery was $20-300 \mathrm{~mL}$. The average time from diagnosis to surgery was 10.6 days (Table 2).

\section{Relationship between EMV and outcomes}

No patient required angiography, embolization, a blood transfusion or became unwell with sepsis. Figure 2 details the participants included in the study and the management of EMV and clinical outcomes. The patient with the highest PSV (148) was diagnosed with RPOC 22 days after surgical management of miscarriage. She initially presented with a history of moderate vaginal bleeding but was clinically stable and had a bleeding score of 1 at presentation. She opted for expectant management which took 53 days to complete. There was a weakly positive correlation between the PSV and EBL in those cases surgically managed but this was not significant (spearman's coefficient $0.37, p=0.14)$, Figure 3 . There were no significant differences in the average PSV of each clinical presentation category; incomplete miscarriage (average PSV $48.9 \mathrm{~cm} / \mathrm{sec}$ ), post-surgical management miscarriage (average PSV $51.9 \mathrm{~cm} / \mathrm{sec}$ ) and post medical management of miscarriage (average PSV 53.9cm/sec). 
Long-term follow up of patients following EMV resolution

Of the 40 women in whom EMV was diagnosed and resolved, 25 have had a further pregnancy, 13 have had term vaginal deliveries, four emergency caesarean sections, five elective caesarean sections and one on-going viable pregnancy at the time of publication. Two delivery outcomes were unknown as the patients transferred out of the trust for personal reasons. $56 \%(14 / 25)$ of those that went on to conceive had successful expectant management of EMV and $44 \%(11 / 25)$ had surgical management. The average time to conception since EMV was 11 months (range, 2-30months). 


\section{Discussion}

We have shown in our series of women that both expectant and surgical management were safe options in women diagnosed with EMV on ultrasound scan after first trimester miscarriage. No women required emergency intervention whether they underwent expectant management or surgical intervention. If managed expectantly, EMVs in our series resolved over time without complications, although the time to resolution was significantly greater when compared with surgery. The initial presence of EMV was associated with the presence of RPOCs, and this was histologically confirmed in all surgically managed cases.

\section{Strengths and Limitations}

A strength of our study is that the data were collected prospectively and consecutive cases with an EMV were included. It is also the largest case series in the literature in relation to EMV and miscarriage. The ultrasound parameters were also collected in a standardised way. Cases with EMV were routine referrals and were not selected from other centres so our findings may be generalizable to other units. A weakness is that the numbers do not permit us to give categorical insights into complications and risks, although our data would suggest that these are lower than previously thought. Although the mechanism is unclear, the association between EMV and RPOCs may suggest EMV relates to the pathophysiology of miscarriage. All patients attending the early pregnancy unit and presenting with a first trimester miscarriage were examined for the presence of enhanced myometrial vascularity and referred to the same clinicians KG/TB. However, not all patients were initially scanned by the same person and so this could introduce selection bias. Once the case was referred the diagnosis was confirmed by one of two clinicians (KG or TB). We believe this will have resulted in consistent results. We did not carry out a formal reproducibility study for 
PSV, although the operator KG was trained by TB and all cases were reviewed on a weekly basis at a multidisciplinary meeting.

The current literature paints a varied clinical picture of the outcome for women with EMV. Only a few retrospective studies have focused on EMV following miscarriage and the natural history is poorly understood. In a study of 18 cases, and in a recent retrospective review of 31 cases, those with RPOC and EMV that were surgically managed were associated with minimal complications. 7,12 These results are in keeping with the findings of our study. On the other hand, a retrospective review of 27 cases by Timor-Tritsch et al reported that nine patients required embolization, three had a blood transfusion and two underwent hysterectomies. However, the population in this study was different to ours as the majority of interventions related to women with caesarean scar pregnancies, and both women who underwent hysterectomies had a placenta percreta confirmed on histology. ${ }^{1}$ Further work by Timmerman et al found varied clinical outcomes in 30 cases with EMV, with 8/30 patients undergoing embolization. However, true AVM was only confirmed in a third of these cases at angiography. ${ }^{15}$ This also questions the accuracy of US findings distinguishing between EMV and true AVM.

Previous studies have suggested that a PSV of $\geq 83 \mathrm{~cm} / \mathrm{sec}$ within the region of EMV is associated with heavy bleeding and embolization ${ }^{1,15}$. In our study, there were three cases with a PSV $\geq 83 \mathrm{~cm} / \mathrm{sec}$, and none required embolization. The way PSV is measured has also been investigated and a standardised approach demonstrated consistently higher PSV values. Therefore it is difficult to compare cases in the current literature. ${ }^{13}$

\section{Clinical Implications}


AVM, whether congenital or acquired is rare. Previous reports have advised against curettage in cases with a suspected AVM as it was thought to lead to life threatening haemorrhage. ${ }^{8}$ The minimal adverse outcomes seen in our study with expectant and surgical management, suggests that it is unlikely that we are seeing cases of acquired AVM following miscarriage and it is more likely to fit with the concept of transient enhanced myometrial vascularity (EMV). This study did not address second trimester termination of pregnancy, caesarean scar pregnancy and molar pregnancy, which may be more likely to be associated with true AVM's, which can only be diagnosed using angiography. Enhanced myometrial vascularity is a transient phenomenon post miscarriage and it appears safe to offer women both expectant and surgical management. The flow chart in Figure 4 aims to provide an algorithm to incorporate the US and clinical features to guide clinical management.

\section{Conclusion}

We have shown that EMV is likely to resolve with time without intervention. All cases in our series were associated with the presence of RPOC, and removal of these was uncomplicated in all cases and led to prompt resolution of the EMV. Our observations suggest that EMV is related to retained products of conception and represent a natural manifestation of the pathophysiology of miscarriage. 


\section{References}

1. Timor-Tritsch IE, Haynes MC, Monteagudo A, Khatib N, Kovacs S. Ultrasound diagnosis and management of acquired uterine enhanced myometrial vascularity/arteriovenous malformations. Am J Obstet Gynecol 2016; 214: 731.e731731.e710.

2. Polat $P$, Suma S, Kantarcy M, Alper F, Levent A. Color Doppler US in the evaluation of uterine vascular abnormalities. Radiographics 2002; 22: 47-53.

3. Mulliken JB, Glowacki J. Hemangiomas and vascular malformations in infants and children: a classification based on endothelial characteristics. Plast Reconstr Surg 1982; 69: 412-422.

4. Flynn MK, Levine $\mathrm{D}$. The noninvasive diagnosis and management of a uterine arteriovenous malformation. Obstet Gynecol 1996; 88: 650-652.

5. Wiebe ER, Switzer P. Arteriovenous malformations of the uterus associated with medical abortion. Int J Gynaecol Obstet 2000; 71: 155-158.

6. Timmerman D, Van den Bosch T, Peeraer K, Debrouwere E, Van Schoubroeck D, Stockx L, Spitz B. Vascular malformations in the uterus: ultrasonographic diagnosis and conservative management. Eur J Obstet Gynecol Reprod Biol 2000; 92: 171-178.

7. Van den Bosch T, Van Schoubroeck D, Timmerman D. Maximum Peak Systolic Velocity and Management of Highly Vascularized Retained Products of Conception. J Ultrasound Med 2015; 34: 1577-1582.

8. Manolitsas T, Hurley V, Gilford E. Uterine arteriovenous malformation--a rare cause of uterine haemorrhage. Aust N Z J Obstet Gynaecol 1994; 34: 197-199.

9. Abu Musa A, Hata T, Hata K, Kitao M. Pelvic arteriovenous malformation diagnosed by color flow Doppler imaging. AJR Am J Roentgenol 1989; 152: 1311-1312.

10. Mungen E, Yergok YZ, Ertekin AA, Ergur AR, Ucmakli E, Aytaclar S. Color Doppler sonographic features of uterine arteriovenous malformations: report of two cases. Ultrasound Obstet Gynecol 1997; 10: 215-219.

11. Van Schoubroeck D, Van den Bosch T, Scharpe K, Lu C, Van Huffel S, Timmerman D. Prospective evaluation of blood flow in the myometrium and uterine arteries in the puerperium. Ultrasound Obstet Gynecol 2004; 23: 378-381.

12. Groszmann YS, Healy Murphy AL, Benacerraf BR. Diagnosis and Management of Patients with Enhanced Myometrial Vascularity Associated with Retained Products of Conception. Ultrasound Obstet Gynecol 2017. DOI:10.1002/uog.18954.

13. Kaelin Agten A, Ringel N, Ramos J, Timor-Tritsch IE, Agten CA, Monteagudo A. Standardization of peak systolic velocity measurement in enhanced myometrial vascularity. Am J Obstet Gynecol 2016; 215: 802-803.

14. Bottomley C, Van Belle V, Mukri F, Kirk E, Van Huffel S, Timmerman D, Bourne T. The optimal timing of an ultrasound scan to assess the location and viability of an early pregnancy. Hum Reprod 2009; 24: 1811-1817. 
15. Timmerman D, Wauters J, Van Calenbergh S, Van Schoubroeck D, Maleux G, Van Den Bosch T, Spitz B. Color Doppler imaging is a valuable tool for the diagnosis and management of uterine vascular malformations. Ultrasound Obstet Gynecol 2003; 21: 570-577. 


\section{Figure legends}

Figure 1A depicts the PSV being measured within the rich vascular network. The pulse repetition frequency (PRF) is increased to isolate the vessels with highest velocity.

Figure 1B and C represents a B mode and corresponding color Doppler image of enhanced myometrial vascularity

Figure 2 demonstrates the participants included in the study and the management of enhanced myometrial vascularity.

Figure 3. The relationship between peak systolic velocity and documented estimated blood loss in those cases surgically managed.

Figure 4. An algorithm detailing a proposed diagnosis and management pathway for the management of enhanced myometrial vascularity.

Key: EMV enhanced myometrial vascularity, RPOC retained products of conception, TVS transvaginal ultrasound. 


\begin{tabular}{ccccccc}
\hline & Age & Parity & $\begin{array}{c}\text { Bleeding } \\
\text { Score }\end{array}$ & $\begin{array}{c}\text { PSV } \\
(\mathrm{cm} / \mathrm{sec})\end{array}$ & $\begin{array}{c}\text { EBL } \\
(\mathrm{mL})\end{array}$ & $\begin{array}{c}\text { Time to } \\
\text { resolution } \\
\text { (days) }\end{array}$ \\
\hline $\begin{array}{c}\text { EMV cases } \\
\text { average, } \\
\text { (range) }\end{array}$ & $34,(22-44)$ & $1.3,(0-7)$ & $2.7,(0-4)$ & $50,(20-148)$ & $76,(20-300)$ & $39,(3-87)$ \\
\hline
\end{tabular}

Table 1.A The average values and ranges for variables. Further details are presented in supplementary materials Table 1B. PSV - peak systolic velocity, EBL- Estimated Blood Loss documented at the time of evacuation of retained products and hysteroscopy, Bleeding score uses a pictorial blood assessment chart where $0=$ no bleeding $1=$ minimal, $2=$ moderate, $3=$ soaked sanitary towel and $4=$ flooding or passing clots. 


\begin{tabular}{|c|c|c|c|c|c|c|c|c|c|c|c|c|c|}
\hline Case & Age & Parity & $\begin{array}{l}\text { Clinical } \\
\text { Presentation }\end{array}$ & $\begin{array}{l}\text { Bleeding } \\
\text { Score }\end{array}$ & $\begin{array}{l}\text { Surgical } \\
\text { History }\end{array}$ & $\begin{array}{l}\text { PSV } \\
(\mathrm{cm} / \mathrm{sec})\end{array}$ & RPOC & Clinical course & $\begin{array}{l}\text { EBL } \\
\text { (ml) }\end{array}$ & $\begin{array}{l}\text { Blood } \\
\text { Transfusion }\end{array}$ & $\begin{array}{l}\text { Reason for } \\
\text { Intervention }\end{array}$ & $\begin{array}{l}\text { Days to } \\
\text { Resolution }\end{array}$ & $\begin{array}{l}\text { RPOC } \\
\text { confirmed } \\
\text { on } \\
\text { histology? }\end{array}$ \\
\hline 1 & 34 & 4 & $\begin{array}{l}\text { Incomplete } \\
\text { Miscarriage }\end{array}$ & 3 & $\mathrm{Nil}$ & 30 & $\mathrm{Y}$ & $\begin{array}{l}\text { Expectant } \\
\text { with serial US }\end{array}$ & & No & & 50 & \\
\hline 2 & 32 & 1 & $\begin{array}{l}\text { Medical } \\
\text { management } \\
\text { of } \\
\text { miscarriage }\end{array}$ & 1 & Nil & 65 & $\mathrm{Y}$ & $\begin{array}{l}\text { Expectant } \\
\text { with serial US }\end{array}$ & & No & & 84 & \\
\hline 3 & 38 & 1 & Post SMM & 1 & Nil & 148 & $\mathrm{Y}$ & $\begin{array}{l}\text { Expectant } \\
\text { with serial US }\end{array}$ & & No & & 53 & \\
\hline 4 & 33 & 6 & $\begin{array}{l}\text { Incomplete } \\
\text { Miscarriage }\end{array}$ & 4 & $1 \mathrm{CD}$ & 20 & $Y$ & $\begin{array}{l}\text { SMM } \\
\text { followed by } \\
\text { SMM + } \\
\text { hysteroscopy }\end{array}$ & 20 & No & $\begin{array}{l}\text { Patient } \\
\text { wishes }\end{array}$ & 29 & $Y(x 2)$ \\
\hline & 34 & 1 & $\begin{array}{l}\text { Incomplete } \\
\text { Miscarriage }\end{array}$ & 1 & $1 C D$ & 63 & $\mathrm{Y}$ & $\begin{array}{l}\text { Expectant } \\
\text { followed by } \\
\text { SMM + } \\
\text { hysteroscopy }\end{array}$ & 100 & No & $\begin{array}{l}\text { Patient } \\
\text { wishes }\end{array}$ & 30 & $Y$ \\
\hline 6 & 32 & 1 & $\begin{array}{l}\text { Incomplete } \\
\text { Miscarriage }\end{array}$ & 1 & $\mathrm{Nil}$ & 25 & $\mathrm{Y}$ & $\begin{array}{l}\text { SMM } \\
\text { +hysteroscopy }\end{array}$ & 20 & No & $\begin{array}{l}\text { Patient } \\
\text { wishes }\end{array}$ & 5 & $Y$ \\
\hline 7 & & 0 & $\begin{array}{l}\text { Incomplete } \\
\text { Miscarriage }\end{array}$ & 4 & $1 \mathrm{SMM}$ & 60 & $\mathrm{Y}$ & $\begin{array}{l}\text { Expectant } \\
\text { with serial US }\end{array}$ & & No & & 58 & \\
\hline 8 & 27 & 0 & $\begin{array}{l}\text { Incomplete } \\
\text { Miscarriage }\end{array}$ & 4 & Nil & 51 & $\mathrm{Y}$ & $\begin{array}{l}\text { Expectant } \\
\text { with serial US }\end{array}$ & & No & & 62 & \\
\hline$\overline{9}$ & 36 & 1 & $\begin{array}{l}\text { Incomplete } \\
\text { Miscarriage }\end{array}$ & 4 & $\mathrm{Nil}$ & 50 & $\mathrm{Y}$ & $\begin{array}{l}\text { Expectant } \\
\text { with serial US }\end{array}$ & & No & & 41 & \\
\hline 10 & & 2 & $\begin{array}{l}\text { Incomplete } \\
\text { Miscarriage }\end{array}$ & 1 & Nil & 29 & $\mathrm{Y}$ & $\begin{array}{l}\text { Expectant } \\
\text { followed by } \\
\text { SMM }\end{array}$ & 20 & No & $\begin{array}{l}\text { Patient } \\
\text { wishes }\end{array}$ & 40 & $\mathrm{Y}$ \\
\hline 11 & 41 & 1 & Post SMM & 4 & $1 \mathrm{SMM}$ & 33 & $\mathrm{Y}$ & SMM & 20 & No & $\begin{array}{l}\text { Patient } \\
\text { wishes }\end{array}$ & 8 & $\mathrm{Y}$ \\
\hline & 20 & 1 & Post SMM & 0 & $1 \mathrm{SMM}$ & 30 & $\mathrm{Y}$ & $\begin{array}{l}\text { Expectant } \\
\text { with serial US }\end{array}$ & & No & & 59 & \\
\hline$\overline{13}$ & & 2 & $\begin{array}{l}\text { Incomplete } \\
\text { Miscarriage }\end{array}$ & 3 & $2 \mathrm{CD}$ & 102 & $\mathrm{Y}$ & $\begin{array}{l}\text { Expectant } \\
\text { with serial US }\end{array}$ & & No & & 48 & \\
\hline & & 7 & $\begin{array}{l}\text { Incomplete } \\
\text { Miscarriage }\end{array}$ & 2 & $1 \mathrm{SMM}$ & 37 & $\mathrm{Y}$ & $\begin{array}{l}\text { Expectant and } \\
\text { offered SMM } \\
\text { but declined }\end{array}$ & & No & & $\begin{array}{l}\text { Loss to } \\
\text { follow up } \\
\text { lived } \\
\text { abroad }\end{array}$ & \\
\hline 15 & & 2 & Post SMM & 1 & $2 \mathrm{SMM}$ & 40 & $\mathrm{Y}$ & $\begin{array}{l}\text { Expectant } \\
\text { followed by } \\
\text { SMM + } \\
\text { hysteroscopy }\end{array}$ & 20 & No & $\begin{array}{l}\text { Patient } \\
\text { wishes }\end{array}$ & 27 & $\mathrm{Y}$ \\
\hline 16 & 38 & 0 & Post SMM & 4 & $1 \mathrm{SMM}$ & 43 & $\mathrm{Y}$ & $\begin{array}{l}\text { Expectant } \\
\text { followed by } \\
\text { SMM+ } \\
\text { hysteroscopy }\end{array}$ & 20 & No & $\begin{array}{l}>6 \text { weeks no } \\
\text { resolution } \\
\text { and patient } \\
\text { wishes. }\end{array}$ & 63 & $Y$ \\
\hline 17 & & 1 & $\begin{array}{l}\text { Post Medical } \\
\text { Management } \\
\text { Miscarriage }\end{array}$ & 4 & $1 \mathrm{SMM}$ & 60 & $\mathrm{Y}$ & SMM & 50 & No & $\begin{array}{l}\text { Patient } \\
\text { wishes }\end{array}$ & 16 & $Y$ \\
\hline
\end{tabular}




\begin{tabular}{|c|c|c|c|c|c|c|c|c|c|c|c|c|c|}
\hline 18 & 34 & 1 & $\begin{array}{l}\text { Incomplete } \\
\text { Miscarriage }\end{array}$ & 4 & $1 \mathrm{SMM}$ & 54 & $Y$ & $\begin{array}{l}\text { Expectant } \\
\text { with serial US }\end{array}$ & & No & & 75 & \\
\hline 19 & 30 & 0 & $\begin{array}{l}\text { Incomplete } \\
\text { Miscarriage }\end{array}$ & 4 & Nil & 72 & $Y$ & $\begin{array}{l}\text { Expectant } \\
\text { with serial US }\end{array}$ & & No & & 21 & \\
\hline 20 & 30 & 0 & Post SMM & 2 & Nil & 40 & $Y$ & $\begin{array}{l}\text { Expectant } \\
\text { with serial US }\end{array}$ & & No & & 35 & \\
\hline 21 & 35 & 1 & $\begin{array}{l}\text { Incomplete } \\
\text { Miscarriage }\end{array}$ & 4 & $\mathrm{Nil}$ & 30 & $\mathrm{Y}$ & SMM & 50 & No & $\begin{array}{l}\text { Patient } \\
\text { wishes }\end{array}$ & 3 & $Y$ \\
\hline & & 1 & $\begin{array}{l}\text { Post medical } \\
\text { management } \\
\text { miscarriage }\end{array}$ & 4 & Nil & 40 & $Y$ & $\begin{array}{l}\text { Expectant } \\
\text { with serial US }\end{array}$ & & No & & 58 & \\
\hline 23 & 36 & 0 & Post SMM & 2 & $1 \mathrm{SMM}$ & 83 & $\mathrm{Y}$ & $\begin{array}{l}\text { Expectant } \\
\text { followed by } \\
\text { SMM. }\end{array}$ & 150 & No & $\begin{array}{l}\text { Patient } \\
\text { wishes }\end{array}$ & 17 & $Y$ \\
\hline 24 & 28 & 1 & $\begin{array}{l}\text { Incomplete } \\
\text { Miscarriage }\end{array}$ & 0 & Nil & 36 & $Y$ & $\begin{array}{l}\text { Expectant } \\
\text { with serial US }\end{array}$ & & No & & $\begin{array}{l}\text { Viable IUP } \\
\text { in follow } \\
\text { up }\end{array}$ & \\
\hline & 36 & 0 & $\begin{array}{l}\text { Post medical } \\
\text { management } \\
\text { of } \\
\text { miscarriage }\end{array}$ & 2 & $\mathrm{Nil}$ & 30 & $\mathrm{Y}$ & $\begin{array}{l}\text { Expectant } \\
\text { with serial US }\end{array}$ & & No & & 38 & \\
\hline$\overline{26}$ & sc & 0 & $\begin{array}{l}\text { Incomplete } \\
\text { Miscarriage }\end{array}$ & 4 & Nil & 50 & $\mathrm{Y}$ & $\begin{array}{l}\text { Expectant } \\
\text { followed by } \\
\text { SMM and } \\
\text { hysteroscopy. }\end{array}$ & 50 & No & $\begin{array}{l}>6 \text { weeks } \\
\text { no } \\
\text { resolution } \\
\text { and patient } \\
\text { wishes. }\end{array}$ & 57 & $\mathrm{Y}$ \\
\hline 27 & 39 & 0 & Post SMM & 4 & $\mathrm{Nil}$ & 28 & $Y$ & $\begin{array}{l}\text { Expectant } \\
\text { followed by } \\
\text { SMM + } \\
\text { hysteroscopy } \\
\text { (resection) }\end{array}$ & 100 & No & $\begin{array}{l}\text { Patient } \\
\text { wishes }\end{array}$ & 87 & $\mathrm{Y}$ \\
\hline 28 & & 0 & $\begin{array}{l}\text { Incomplete } \\
\text { Miscarriage }\end{array}$ & 3 & Nil & 53 & $Y$ & SMM & 20 & No & $\begin{array}{l}\text { Patient } \\
\text { wishes } \\
\text { (wants IVF) }\end{array}$ & 11 & $\mathrm{Y}$ \\
\hline & & 0 & $\begin{array}{l}\text { Incomplete } \\
\text { Miscarriage }\end{array}$ & 2 & 2 STOP & 57 & $Y$ & $\begin{array}{l}\text { SMM+ } \\
\text { hysteroscopy }\end{array}$ & 50 & No & $\begin{array}{l}\text { Patient } \\
\text { wishes }\end{array}$ & 10 & $\mathrm{Y}$ \\
\hline 30 & 30 & 2 & $\begin{array}{l}\text { Medical } \\
\text { management } \\
\text { of } \\
\text { miscarriage } \\
18 / 40\end{array}$ & 2 & $\mathrm{Nil}$ & 60 & $Y$ & $\begin{array}{l}\text { Expectant } \\
\text { followed by } \\
\text { SMM + } \\
\text { hysteroscopy }\end{array}$ & 200 & No & $\begin{array}{l}\text { Patient } \\
\text { wishes }\end{array}$ & 38 & $\mathrm{Y}$ \\
\hline 31 & 33 & 0 & Post SMM & 2 & $\mathrm{Nil}$ & 22 & $Y$ & SMM & 100 & No & $\begin{array}{l}\text { Patient } \\
\text { wishes }\end{array}$ & 8 & $\mathrm{Y}$ \\
\hline 32 & 36 & 3 & $\begin{array}{l}\text { Incomplete } \\
\text { Miscarriage }\end{array}$ & 4 & $\mathrm{Nil}$ & 32 & $\mathrm{Y}$ & $\begin{array}{l}\text { Expectant } \\
\text { with serial US }\end{array}$ & & No & & 29 & \\
\hline 33 & 30 & 0 & $\begin{array}{l}\text { Incomplete } \\
\text { Miscarriage }\end{array}$ & 4 & Nil & 58 & $\mathrm{Y}$ & $\begin{array}{l}\text { Expectant } \\
\text { with serial US }\end{array}$ & & No & & 26 & \\
\hline 34 & 33 & 1 & $\begin{array}{l}\text { Incomplete } \\
\text { Miscarriage }\end{array}$ & 3 & $\mathrm{Nil}$ & 60 & $Y$ & $\begin{array}{l}\text { Expectant } \\
\text { with serial US }\end{array}$ & & No & & 49 & \\
\hline 35 & 25 & 3 & $\begin{array}{l}\text { Post medical } \\
\text { management } \\
\text { of } \\
\text { miscarriage }\end{array}$ & 4 & $\mathrm{Nil}$ & 75 & $Y$ & $\begin{array}{l}\text { Expectant } \\
\text { with serial US }\end{array}$ & & No & & 56 & \\
\hline
\end{tabular}




\begin{tabular}{|c|c|c|c|c|c|c|c|c|c|c|c|c|c|}
\hline 36 & 44 & 0 & $\begin{array}{l}\text { Incomplete } \\
\text { Miscarriage }\end{array}$ & 2 & $\mathrm{Nil}$ & 87 & $Y$ & $\begin{array}{l}\text { Expectant } \\
\text { with serial US }\end{array}$ & & No & & $\begin{array}{l}\text { Loss to } \\
\text { follow up }\end{array}$ & \\
\hline 37 & 41 & 1 & $\begin{array}{l}\text { Incomplete } \\
\text { Miscarriage }\end{array}$ & 2 & Nil & 28 & $Y$ & $\begin{array}{l}\text { Expectant } \\
\text { with serial US }\end{array}$ & & No & & $\begin{array}{l}\text { Loss to } \\
\text { follow up }\end{array}$ & \\
\hline 38 & 22 & 0 & $\begin{array}{l}\text { Incomplete } \\
\text { Miscarriage }\end{array}$ & 2 & $\mathrm{Nil}$ & 40 & $Y$ & $\begin{array}{l}\text { Expectant } \\
\text { with serial US }\end{array}$ & & No & & $\begin{array}{l}\text { Loss to } \\
\text { follow up }\end{array}$ & \\
\hline 39 & 38 & 4 & $\begin{array}{l}\text { Post medical } \\
\text { management } \\
\text { of } \\
\text { miscarriage }\end{array}$ & 3 & $\mathrm{Nil}$ & $\begin{array}{l}\text { Not } \\
\text { done }\end{array}$ & $Y$ & $\begin{array}{l}\text { Expectant } \\
\text { with serial US }\end{array}$ & & No & & 56 & \\
\hline & & 2 & $\begin{array}{l}\text { Post medical } \\
\text { management } \\
\text { of } \\
\text { miscarriage }\end{array}$ & 1 & $1 \mathrm{SMM}$ & 47 & $Y$ & $\begin{array}{l}\text { Outpatient } \\
\text { hysteroscopy } \\
\text {-failed and } \\
\text { patient } \\
\text { required SMM } \\
\text { +hysteroscopy } \\
\text { under GA. }\end{array}$ & 300 & No & $\begin{array}{l}\text { Patient } \\
\text { wishes }\end{array}$ & 5 & $\mathrm{Y}$ \\
\hline
\end{tabular}

Table 1.B Clinical data and outcomes of those patients with EMV following miscarriage.

Key: CD caesarean delivery, US ultrasound, IUP intrauterine pregnancy, SMM surgical management of miscarriage, STOP surgical termination of pregnancy, RPOC retained products of conception, PSV peak systolic velocity, EBL-Estimated Blood Loss documented at the time of evacuation of retained products and hysteroscopy, GA-General Anaesthetic. The bleeding score uses a pictorial blood assessment chart where $0=$ no bleeding $1=$ minimal, $2=$ moderate, $3=$ soaked sanitary towel and $4=$ flooding or passing clots. 


\begin{tabular}{ccccccc}
\hline Management & $\begin{array}{c}\text { Number } \\
\text { of cases }\end{array}$ & $\begin{array}{c}\text { Number of } \\
\text { cases } \\
\text { resolved }\end{array}$ & $\begin{array}{c}\text { Loss to } \\
\text { follow } \\
\text { up }\end{array}$ & $\begin{array}{c}\text { Number of cases } \\
\text { for further } \\
\text { surgical } \\
\text { intervention }\end{array}$ & $\begin{array}{c}\text { Reason for } \\
\text { intervention }\end{array}$ & $\begin{array}{c}\text { Time to } \\
\text { resolution } \\
\text { (days) }\end{array}$ \\
\hline Expectant & 31 & 18 & 5 & 8 & Patient choice & 48 \\
\hline Surgical & 9 & 7 & 0 & 2 & RPOC & 10.6 \\
\hline
\end{tabular}

Total $\quad 40$

Table 2. Summary of the management of cases with enhanced myometrial vascularity 


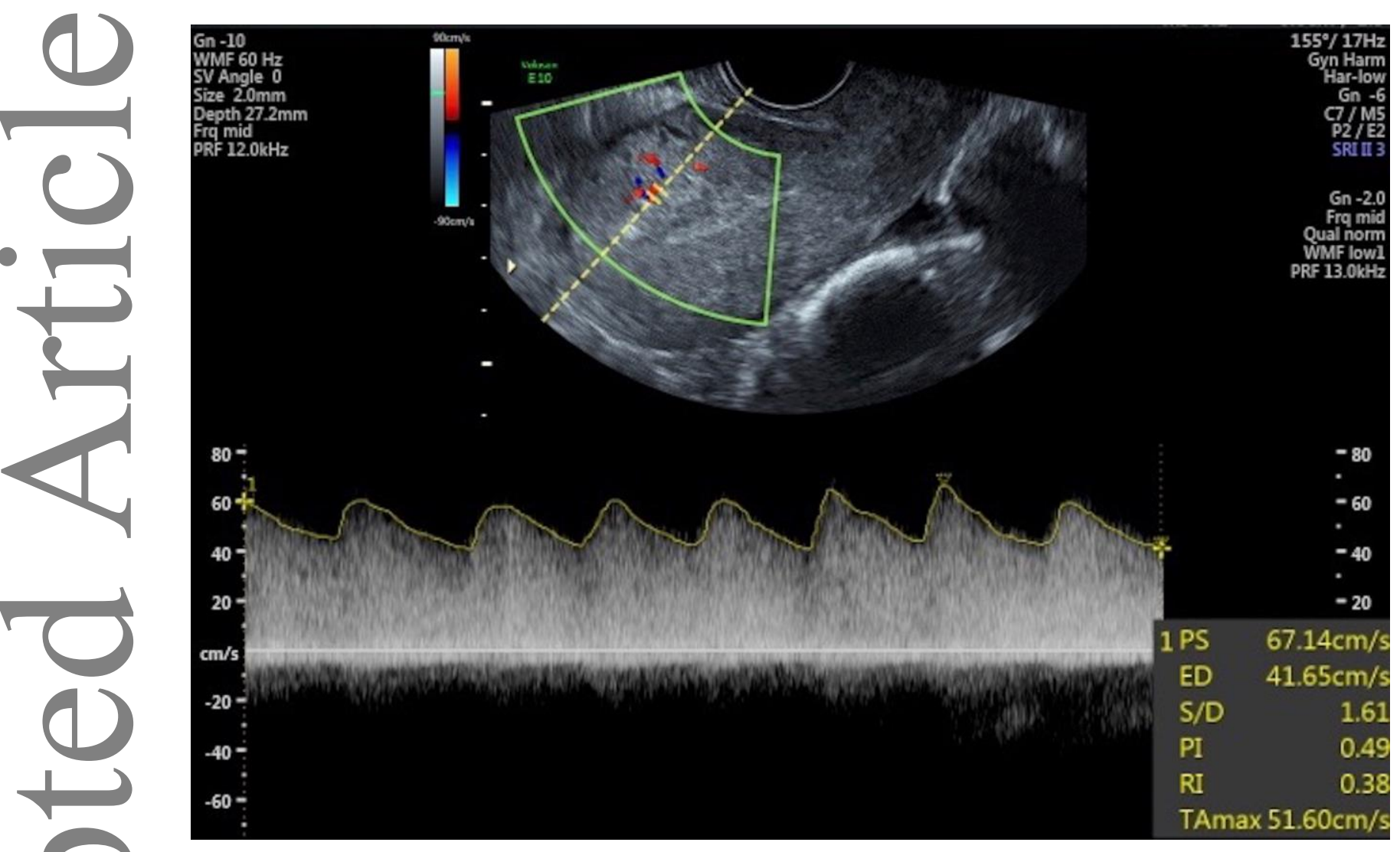




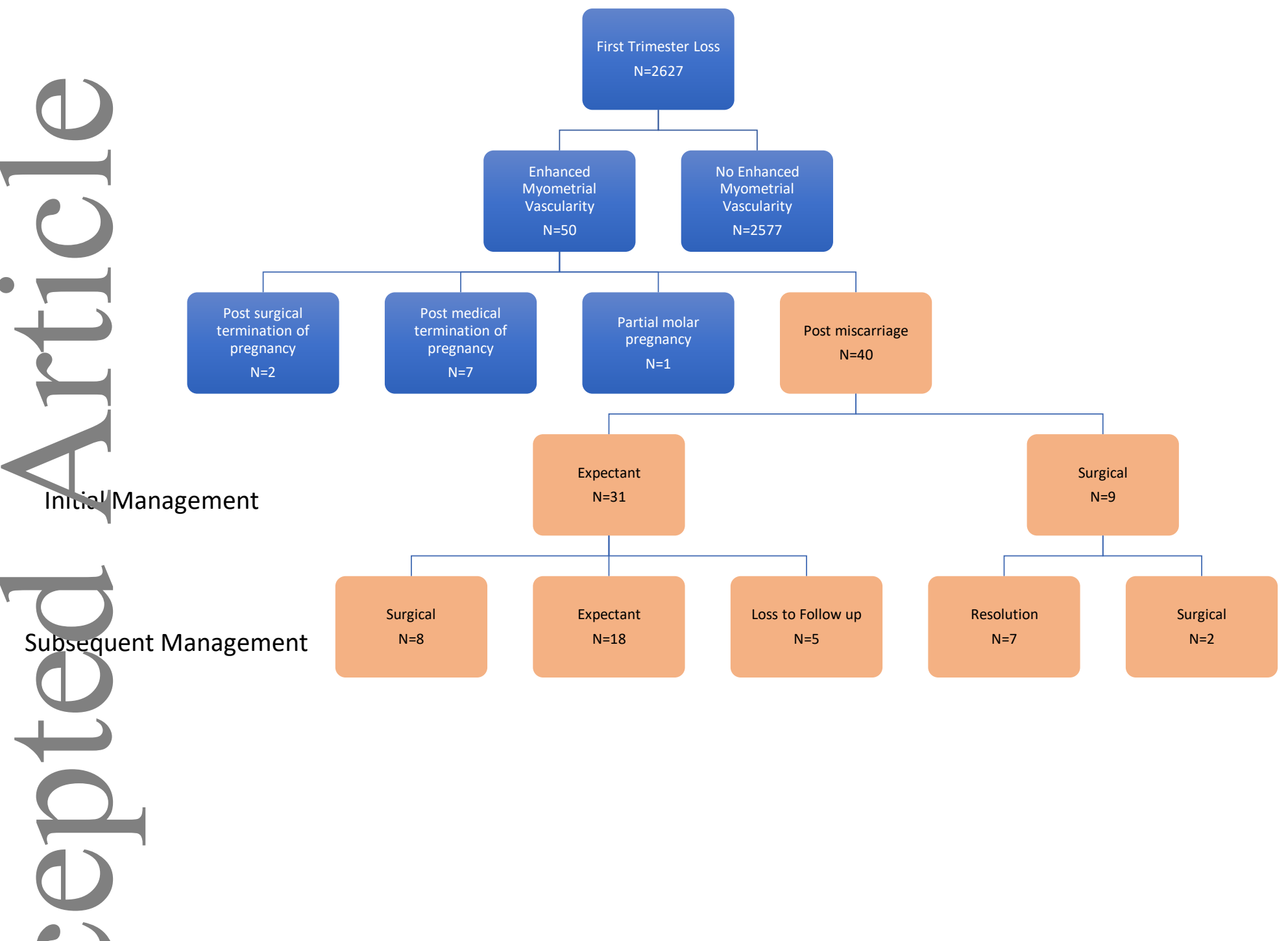

Figure 2 demonstrates the participants included in the study and the management of enhanced myometrial vascularity. 


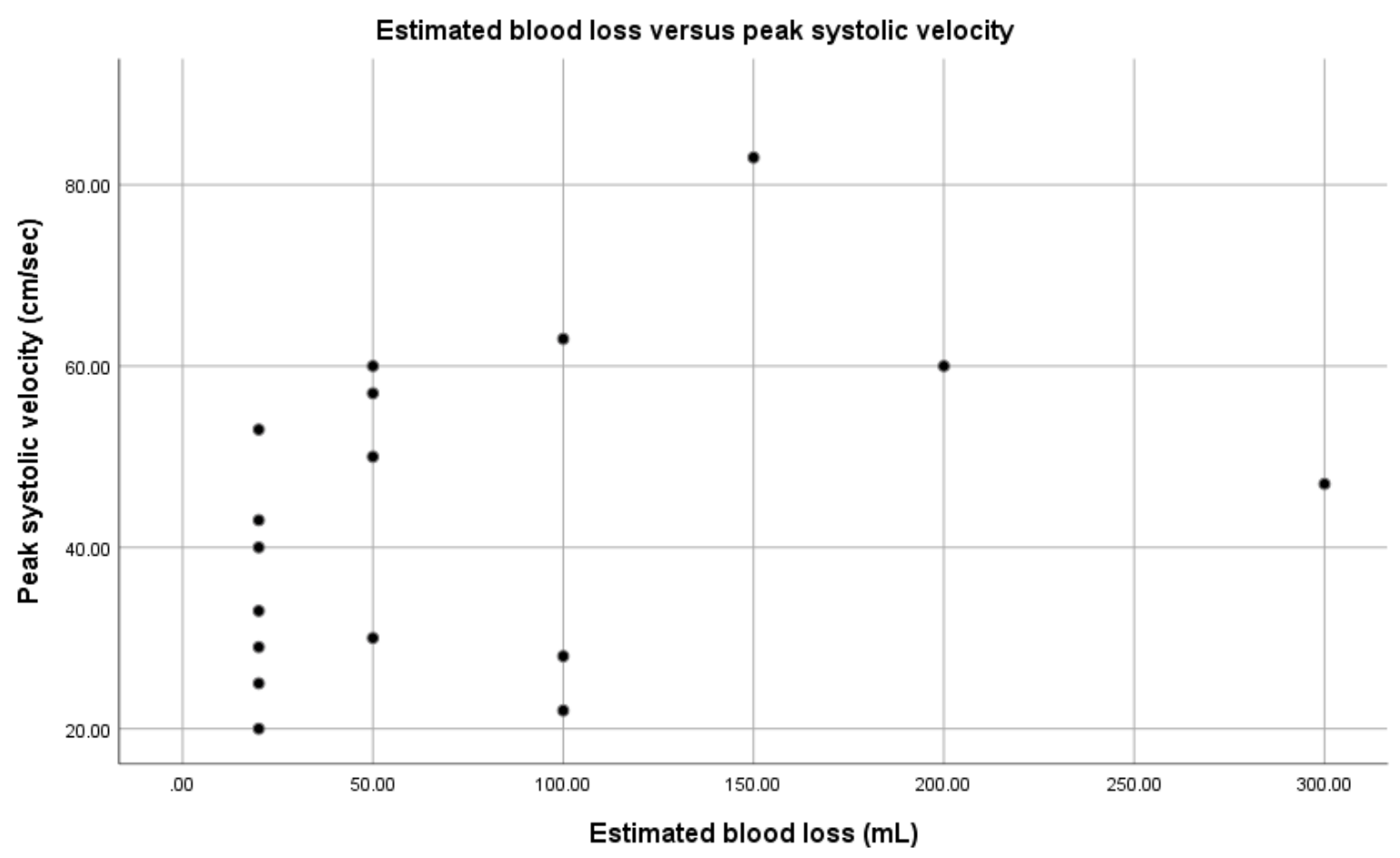

Figure 3. The relationship between peak systolic velocity and documented estimated blood loss in those cases surgically managed. 


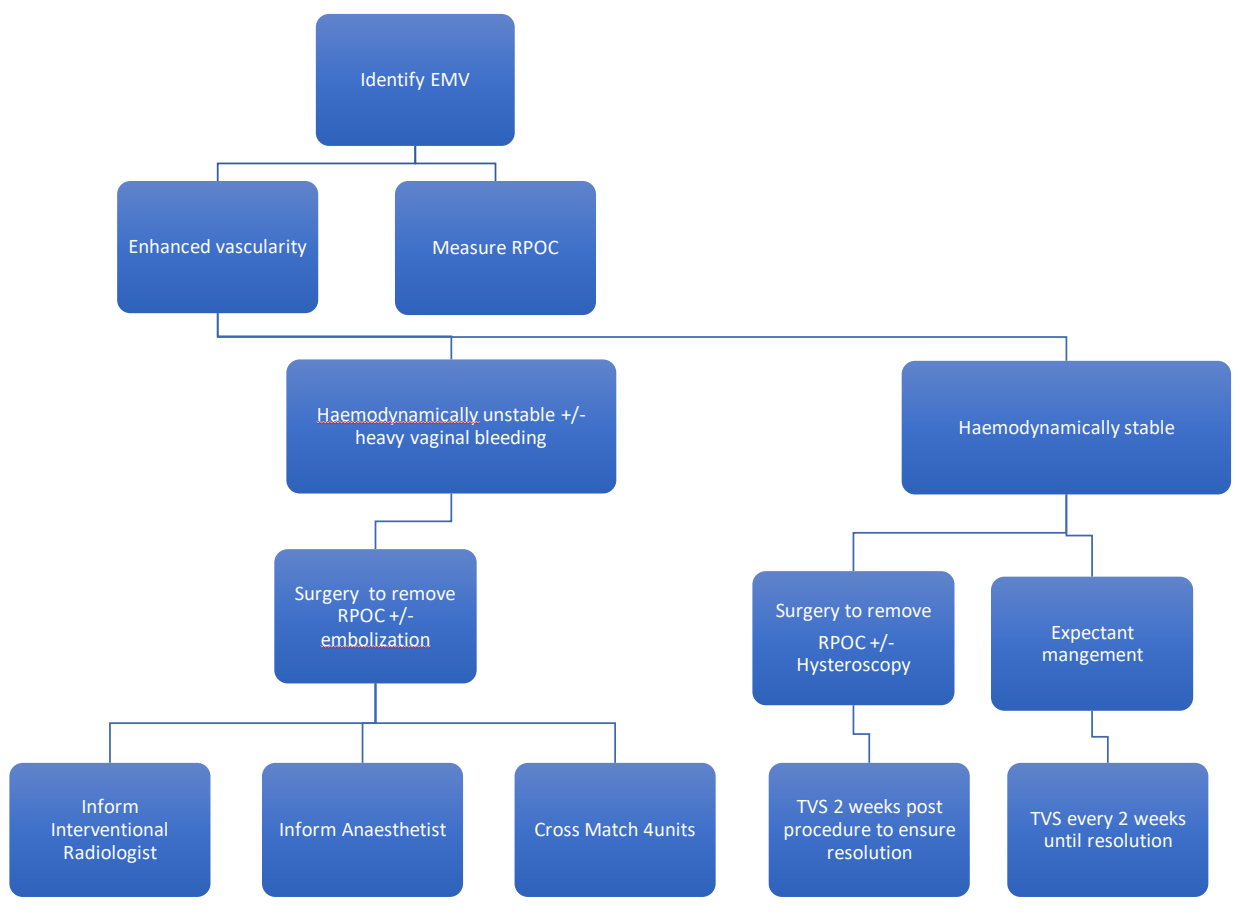

Figure 4. An algorithm detailing a proposed diagnosis and management pathway for the management of enhanced myometrial vascularity.

Key: EMV enhanced myometrial vascularity, RPOC retained products of conception, TVS transvaginal ultrasound. 